\title{
Additive effect of harmane and muscimol for memory consolidation impairment in inhibitory avoidance task
}

Mohammad Nasehi ${ }^{\mathrm{a}}$, Parastu Morteza-zadeh ${ }^{\mathrm{b}}$, Fatemeh Khakpai ${ }^{\mathrm{c}}$, Mohammad-Reza Zarrindast ${ }^{\mathrm{a}, \mathrm{c}, \mathrm{d}, \mathrm{e}, \mathrm{f}, \mathrm{g}, *}$

${ }^{a}$ Medical Genomics Research Center, Tehran Medical Sciences Branch, Islamic Azad University, Tehran, Iran

${ }^{b}$ Department of Biology, Faculty of Basic Sciences, Kharazmi (Tarbiat Moalem) University, Tehran, Iran

${ }^{c}$ Institute for Cognitive Science Studies (ICSS), Tehran, Iran

${ }^{\mathrm{d}}$ Department of Pharmacology School of Medicine, Tehran University of Medical Sciences, Tehran, Iran

${ }^{\mathrm{e}}$ Iranian National Center for Addiction Studies, Tehran University of Medical Sciences, Tehran, Iran

${ }^{\mathrm{f}}$ School of Cognitive Sciences, Institute for Research in Fundamental Sciences (IPM), Tehran, Iran

${ }^{\mathrm{g}}$ Cognitive and Neuroscience Research Center (CNRC), Tehran Medical Sciences Branch, Islamic Azad University, Tehran, Iran 
Corresponding Author: Mohammad-Reza Zarrindast (Zarinmr@ams.ac.ir; Department of Pharmacology, School of Medicine, Tehran University of Medical Sciences, Tehran, Iran)

P.O.Box $13145-784$

Tel: +9821-66402569

Fax: +9821-66402569

E-mail: zarinmr@ams.ac.ir 


\begin{abstract}
In the current study, we examined the effect of bilateral intra-dorsal hippocampal (intra-CA1) microinjections of $\mathrm{GABA}_{\mathrm{A}}$ receptor agents on amnesia induced by a $\beta$-carboline alkaloid, harmane in mice. We used a single-trial stepdown passive avoidance task to assess memory retention and then, open field test to assess locomotor activity. The results indicated that post-training intra-CA1 injections of bicuculline $-\mathrm{a} \mathrm{GABA}_{\mathrm{A}}$ receptor antagonist- had no significant effect, while muscimol (0.01 and $0.1 \mu \mathrm{g} /$ mouse $)-\mathrm{a} \mathrm{GABA}_{\mathrm{A}}$ receptor agonist- impaired memory consolidation. Post-training intra-peritoneal (i.p.) infusion of harmane (3 and $5 \mathrm{mg} / \mathrm{kg}$ ) decreased memory consolidation. Furthermore, post-training intraCA1 administration of sub-threshold dose of bicuculline (0.001 $\mu \mathrm{g} / \mathrm{mouse})$ restored, whereas muscimol $(0.001 \mu \mathrm{g} /$ mouse $)$ potentiated impairment of memory consolidation induced by harmane. The isobologram analysis revealed that there is an additive effect between harmane and muscimol on impairment of memory consolidation. Moreover, all above doses of drugs did not alter locomotor activity. These findings suggest that $\mathrm{GABA}_{\mathrm{A}}$ receptors of the CA1 area, at least partly, play a role in modulating the effect of harmane on memory consolidation.
\end{abstract}

Keywords: Harmane, $\mathrm{GABA}_{\mathrm{A}}$ receptor, the CA1 area, step-down passive avoidance, memory 


\section{Introduction}

$\gamma$-amino butyric acid (GABA) is the main inhibitory neurotransmitter in the brain, which affects learning and memory processes (Jafari-Sabet and JannatDastjerdi, 2009, Parsaei et al., 2011). GABA elicit its action through binding to particular membrane receptors which are divided into three major subclasses: $\mathrm{GABA}_{\mathrm{A}}, \mathrm{GABA}_{\mathrm{B}}$ and $\mathrm{GABA}_{\mathrm{C}}$ receptors (Bormann, 2000, Semyanov and Kullmann, 2002). $\mathrm{GABA}_{\mathrm{A}}$ and $\mathrm{GABA}_{\mathrm{C}}$ receptors are coupled with $\mathrm{Cl}^{-}$channels (McDonald and Moss, 1994, Bormann, 2000), while the $\mathrm{GABA}_{\mathrm{B}}$ receptors are coupled with G-protein and linked to $\mathrm{K}^{+}$channels (Bowery, 1993, Thompson, 1994). GABA has a controlling role on the balance of excitability and inhibitory states in the cortex and hippocampus (Paulsen and Moser, 1998, Khakpai et al., 2013a). The hippocampus has many GABAergic neurons (Farahmandfar et al., 2011), and these neurons originate from the septum (Drake and Milner, 1999). The GABAergic neurons in the hippocampus are involved in learning and memory processes by participation in information processing in the hippocampus (Paulsen and Moser, 1998, Khakpai et al., 2013a). The hippocampus is known as a main area for synaptic plasticity, long-term potentiation (LTP), acquisition, consolidation and retrieval of memory (Khakpai et al., 2013b).

Harmane (1-methyl-9H-pyrido[3,4-b]indole) is a potent $\beta$-carboline alkaloid which induces tremor in laboratory animals (McKenna, 1996). It is produced 
endogenously in peripheral and brain tissue by the Pictet-Spengler condensation reaction between an indoleamine and acetaldehyde (Bonnet et al., 2008). In addition, exogenous harmane from coffee or cigarette smoke may reach the brain (Herraiz and Chaparro, 2006). This molecule has a critical role in the modulation of learning and memory functions (Moura et al., 2006, Celikyurt et al., 2013). Harmane has been indicated to interact with a variety of receptor mechanisms in the brain such as benzodiazepines, serotonin and dopamine (Ergene and Schoener, 1993). Evidences exhibited that harmane is the most potent endogenously inhibitor of benzodiazepine binding site of the $\mathrm{GABA}_{\mathrm{A}}$ receptors. Moreover, researchers suggested that harmane could act as the endogenous ligand of the benzodiazepine binding site of the $\mathrm{GABA}_{\mathrm{A}}$ receptors (Muller et al., 1981). Also, harmane increases the electrically stimulated release of the transmitter through GABAergic axons whatever the effect on benzodiazepine-binding regions of the GABA receptors (Dolzhenko and Komissarov, 1984). Because harmane and GABA receptors have interaction (Muller et al., 1981, Dolzhenko and Komissarov, 1984, Mousah et al., 1986), and considering the role of hippocampus (Khakpai et al., 2013b), harmane (Moura et al., 2006, Celikyurt et al., 2013), and GABA receptors in memory process, the aim of the present study was to investigate the effects of harmane and GABA receptors on memory consolidation and locomotor activity in the stepdown passive avoidance and open field test. 


\section{Materials and methods}

\subsection{Animals}

Adult male NMRI mice which weighed 25-30 g obtained from the University of Tehran (Tehran, Iran) were used. Ten mice were housed in standard polypropylene cage colonies maintained at $23 \pm 1^{\circ} \mathrm{C}$ under a 12 -h light: 12 -h dark cycle (lights on at 07:00) with water and food freely available. Subjects were handled about 3 min each day previous to behavioral testing. Behavioral tests were carried out during the light phase of the cycle between 8:00 a.m. and 12:00 p.m. The current investigation was approved by the Ethics Committee of the Faculty of Science of the University of Tehran which corresponds to the national guidelines for animal care and use.

\subsection{Cannula guide implantation}

Animals were anesthetized with intra-peritoneal (i.p.) injections of ketamine hydrochloride $(50 \mathrm{mg} / \mathrm{kg})$ plus xylazine $(5 \mathrm{mg} / \mathrm{kg})$ and positioned in a stereotaxic apparatus (Stoelting Co, Illinois, USA). Then, the skin was incised and the skull was cleaned. Two 22-gauge guide cannulae ( $8 \mathrm{~mm}$ length) were bilaterally placed $1 \mathrm{~mm}$ above the dorsal hippocampus (CA1). The following coordinates were done based on the atlas of Paxinos and Franklin (Paxinos and Franklin, 2001). 
Stereotaxic coordinates for the CA1 regions of the hippocampus were: anteroposterior $(\mathrm{AP})=-2 \mathrm{~mm}$ from the bregma, mediolateral $(\mathrm{ML})= \pm 1.6$ from the sagittal suture and dorsoventral $(\mathrm{DV})=-1.5 \mathrm{~mm}$ from the skull surface. The cannulae were secured to the skull with dental acrylic cement. Two stainless steel stylets (27-gauge) were inserted into the guide cannula to inhibit possible obstruction. All mice were allowed a week recovery period from surgery and the effect of the anesthetic agents previous to being used in the experiments.

\subsection{Memory testing and apparatus}

The inhibitory avoidance apparatus consist of a wooden box $(30 \mathrm{~cm} \times 30 \mathrm{~cm}$ $\times 40 \mathrm{~cm})$ with a floor which consisted of parallel stainless steel rods $(0.3 \mathrm{~cm}$ in diameter, spaced $1 \mathrm{~cm}$ apart). A wooden platform $(4 \mathrm{~cm} \times 4 \mathrm{~cm} \times 4 \mathrm{~cm})$ was fixed in the center of the grid floor. Electric shocks ( $1 \mathrm{~Hz}, 0.5 \mathrm{~s}$ and $50 \mathrm{VDC})$ were delivered to the grid floor via an isolated stimulator (Grass S44, Quincy, MA, USA).

For testing, each mouse was quietly placed on the wooden platform. Once mouse stepped down from the platform and put all its paws on the grid floor, intermittent electric shocks were delivered continuously for $15 \mathrm{~s}$. This training procedure was carried out among 8:00 a.m. and 12:00 p.m. Shock parameters are bristle hair, startle and freezing. Twenty-four hours after training, each subject was 
placed on the platform again, and the step-down latency was recorded with a stopwatch as passive avoidance behavior. An upper cut-off time of 5 min was set. The retrieval test was also performed among 8:00 a.m. and 12:00 p.m.

\subsection{Measurement of locomotor activity}

The locomotion apparatus (Borj Sanat Co, Tehran, Iran) consist of clear perspex container box $(30 \mathrm{~cm} \times 30 \mathrm{~cm} \times 40 \mathrm{~cm})$. The apparatus has a gray perspex panel $(30 \mathrm{~cm} \times 30 \mathrm{~cm}, 2.2 \mathrm{~cm}$ thick) with 16 photocells which divided the box to 16 equal-sized squares. The locomotor activity was recorded as the number of crossings from one square to another during $5 \mathrm{~min}$.

\subsection{Drugs}

The drugs used in the present study were harmane from Sigma (St. Louis, MO), bicuculline (Tocris, Bristol, UK) and muscimol (Tocris, Bristol, UK). The time of infusion and doses of the drugs used in the experiments were chosen according to pilot studies and published work in scientific literature (Yousefi et al., 2012, Nasehi et al., 2013). The compounds were tested at doses: harmane: 1, 3 and $5 \mathrm{mg} / \mathrm{kg}$, bicuculline: $0.001,0.01$, and $0.1 \mu \mathrm{g} / \mathrm{mouse}$, muscimol: $0.001,0.01$, and $0.1 \mu \mathrm{g} /$ mouse. Harmane was dissolved in $0.9 \%$ physiological saline and the 
compound was stirred for $1 \mathrm{~h}$ before obtaining the final solution; bicuculline and muscimol were dissolved in $0.9 \%$ physiological saline, just before the experiments.

\subsection{Drug treatment}

For drug injection, subjects were restrained gently by hand; the stylets were removed from the guide cannulae and substituted by 27 -gauge injection needles ( $1 \mathrm{~mm}$ below the tip of the guide cannulae). The infusion solutions were manually injected over a $60 \mathrm{~s}$ period. The injection needles were left in place for an extra 60 $\mathrm{s}$ to facilitate the diffusion of drugs. The protocol has been clarified in Table 1.

\section{[Table 1 here]}

\subsection{Statistical analysis}

Since individual variations in the step-down apparatus data, we analyze data via Kruskal-Wallis nonparametric one-way analysis of variance (ANOVA) followed by a two-tailed Mann-Whitney’s U-test. Holmes Sequential Bonferroni Correction Test was done for paired comparisons when appropriate. The median as well as interquartile ranges of the step-down latencies were recorded for ten subjects in each experimental group. One/two-way ANOVA followed by post-hoc test was carried out for the statistical evaluation in the locomotor activity. 
Furthermore, isobolographic analysis was performed to evaluate the interactions following injection of the two drugs (Naseri et al., 2014). The ED50 of each drug (2.66 mg/kg for harmane and $0.052 \mathrm{mg} / \mathrm{kg}$ for muscimol) was determined by linear regression analysis and combination of the two drugs was injected in a constant dose ratio based on ED50 values. For drug combinations, the theoretic ED50 is harmane ED50/2 + muscimol ED50/2. Experimental values of drug combinations from fixed ratio-calculated were also analyzed by the regression analysis, after which the experimental ED50 value of the drug combinations was calculated (\%50 step-down latency). The statistical significance of the difference between the theoretical ED50 and experimental ED50 of the drug combinations was evaluated by the one-sample t-test. When the experimental ED50 was significantly lower than the theoretical ED50 a synergistic interaction between harmane and muscimol could be inferred, while there was not any difference between them showing additive interaction rather than synergistic effect (Naseri et al., 2014). Differences with $\mathrm{P}<0.05$ between the experimental groups at each point were indicated statistically significant. Statistical analysis was done by SPSS software ver. 19.

\subsection{Experimental design}


Ten animals were used in each experimental group and each animal was only tested once. Bilateral intra-CA1 administrations of drugs were in a volume of $1 \mu 1 /$ mouse $(0.5 \mu 1 /$ each side $)$. All administrations were performed immediately after training. In experiments that mice received two injections, firstly harmane injected then bicuculline or muscimol administrated. Interval time between two injections was 5 min.

\subsubsection{Experiment 1}

This experiment examined the effect of post-training intra-CA1 injection of $\mathrm{GABA}_{\mathrm{A}}$ receptor drugs on inhibitory avoidance (IA) memory consolidation and locomotor activity. Eight groups of animals were used. Four groups of animals received vehicle $(1 \mu \mathrm{l} / \mathrm{mouse})$ or different doses of bicuculline $(0.001,0.01$, and $0.1 \mu \mathrm{g} / \mathrm{mouse})$ just after training. The other four groups received saline (1 $\mu 1 /$ mouse $)$ or diverse doses of muscimol $(0.001,0.01$, and $0.1 \mu \mathrm{g} /$ mouse $)$ just after training.

\subsubsection{Experiment 2}

Experiment 2 evaluated the effects of post-training intra-CA1 administration of $\mathrm{GABA}_{\mathrm{A}}$ receptor drugs on memory consolidation and locomotor activity under the amnesia induced by harmane. Twelve groups of animals were used. The 
animals received saline $(1 \mu \mathrm{l} / \mathrm{mouse})$ or different doses of harmane $(1,3$ and 5 $\mathrm{mg} / \mathrm{kg}$ ) just after training. These mice received intra-CA1 post-training vehicle (1 $\mu 1 /$ mouse $)$, sub-threshold dose of bicuculline (0.001 $\mu \mathrm{g} /$ mouse $)$ or muscimol (0.001 $\mu \mathrm{g} /$ mouse) just after training.

\subsubsection{Experiment 3}

According to the dose-response curve of harmane and muscimol, animals received administration of harmane $1.33 \mathrm{mg} / \mathrm{kg}+$ muscimol $0.026 \mathrm{mg} / \mathrm{kg}$, harmane $0.66 \mathrm{mg} / \mathrm{kg}+$ muscimol $0.013 \mathrm{mg} / \mathrm{kg}$ and harmane $0.33 \mathrm{mg} / \mathrm{kg}+$ muscimol 0.006 $\mathrm{mg} / \mathrm{kg}$, immediately after training (Naseri et al., 2014).

\section{Results}

\subsection{Effects of $\mathrm{GABA}_{\mathrm{A}}$ receptor drugs on IA memory consolidation and locomotor activity}

Fig. 1 shows the effects of post-training intra-CA1 infusion of bicuculline and muscimol on the step-down latency and locomotor activity. Kruskal-Wallis ANOVA revealed that post-training administration of bicuculline $(\mathrm{H}(3)=1.351$, $\mathrm{P}>0.05$, fig. 1A; left panel) did not alter, while muscimol $(\mathrm{H}(3)=29.011, \mathrm{P}<0.001$, fig. 1A; right panel) decreased the step-down latency. Post hoc analysis by MannWhitney's U-test indicated that muscimol (0.01, and $0.1 \mu \mathrm{g} /$ mouse) impaired 
memory consolidation, thus revealed an amnesic effect. Moreover, one-way ANOVA exhibited that bicuculline $[\mathrm{F}(3,36)=0.467, \mathrm{P}>0.05$, Fig. 1B; left panel $]$ and muscimol $[\mathrm{F}(3,36)=0.072, \mathrm{P}>0.05$, Fig. 1B; right panel $]$ did not change locomotor activity.

[Fig.1 here]

\subsection{Effects of post-training $\mathrm{GABA}_{\mathrm{A}}$ receptor drugs administration on IA memory consolidation and locomotor activity under amnesia induced by harmane}

The data of Fig. 2A left panel indicated that harmane at doses of 3 and 5 $\mathrm{mg} / \mathrm{kg}$ impaired memory consolidation [Kruskal-Wallis ANOVA analysis $(\mathrm{H}(3)=23.107, \mathrm{P}<0.001)$ followed by Mann-Whitney's U-test]. Moreover, one way ANOVA revealed that harmane did not alter locomotor activity $[F(3,36)=0.249$, P>0.05, Fig. 2B; left panel].

Furthermore, Kruskal-Wallis analysis revealed that a sub-threshold dose of bicuculline $(0.001 \mu \mathrm{g} /$ mouse) reversed memory impairment caused by harmane ( 3 and $5 \mathrm{mg} / \mathrm{kg}$ ) [Kruskal-Wallis ANOVA, $\mathrm{H}(3)=13.531, \mathrm{P}<0.01$, Fig. 2A; middle panel]. Also, two-way ANOVA displayed that these interventions did not alter locomotor activity $[\mathrm{F}(7,56)=0.273, \mathrm{P}>0.05$, Fig. $2 \mathrm{~B}$; middle panel $]$. 
In Fig. 2A right panel are seen the effects of muscimol on amnesia induced by harmane [Kruskal-Wallis ANOVA, H(3)=19.370, P<0.001]. Mann-Whitney's U-test analysis indicated that a sub-threshold dose of muscimol (0.001 $\mu \mathrm{g} / \mathrm{mouse})$ potentiated memory impairment induced by harmane $(5 \mathrm{mg} / \mathrm{kg})$. Moreover, twoway ANOVA exhibited that these interventions did not modify locomotor activity $[F(7,56)=0.454, \mathrm{P}>0.05$, Fig. 2B; right panel $]$.

[Fig.2 here]

\subsection{The additive effects between harmane and muscimol on IA memory consolidation deficit}

To confirm whether harmane and muscimol injection would exert additive or synergistic effects on their induced memory consolidation deficit, the isobolographic analysis was done to compare the theoretical and experimental ED50 of the drugs when administered together. The theoretical additive line showed that at all points, harmane and muscimol combination produced an effect of theoretical 50\% step-down latency (theoretical ED50) according to an additive interaction (Fig. 3). One sample t-test revealed that there is no significant difference between experimental ED50 and theoretical ED50. Our data suggested an additive effect of harmane and muscimol administration upon induction of IA memory consolidation deficit (Fig. 3). 


\section{[Fig.3 here]}

\subsection{Histology}

After the testing sessions each subject was deeply anesthetized and 0.5 $\mu 1 /$ site of a $4 \%$ methylene-blue solution was injected into the CA1, as explained in the drug section, then decapitated and its brain removed and located in formaldehyde (10\%). After some days, the brains were sliced and the sites of infusions were confirmed according to the atlas of Paxinos and Franklin (Paxinos and Franklin, 2001). Only the data from mice with correct cannulae implants were used in the statistical analyses.

\section{[Fig.4 here]}

\section{Discussion}

There is extensive reports showing that administration of GABAergic agents affect learning and memory retention (Nakagawa and Iwasaki, 1995, Chapouthier and Venault, 2002, Zarrindast et al., 2004, Azizbeigi et al., 2013, Heysieattalab et al., 2015). Evidences indicated that mostly GABAergic agonists impaired memory and their antagonists improved recall (Farr et al., 2000, Chapouthier and Venault, 2002, Ramirez et al., 2005, Zarrindast et al., 2006, Yousefi et al., 2012). The hippocampal GABAergic interneurons play a potential role in spatial and temporal 
conditions for the modification of synaptic plasticity during the hippocampusdependent memory processes (Paulsen and Moser, 1998). Our results showed that post-training intra-CA1 injection of bicuculline had no significant effect on memory consolidation and locomotor activity. In agreement with our data, some reports have shown that injection of bicuculline in to the CA1 (Yousefi et al., 2013), basolateral amygdala (Kangarlu-Haghighi et al., 2015), nucleus accumbens (Azizbeigi et al., 2013), nucleus basalis magnocellularis (Moron et al., 2002), and posterior striatum (Brioni et al., 1990) did not alter memory. Other investigators have reported that blockade of $\mathrm{GABA}_{\mathrm{A}}$ receptors in the hippocampus through administration of bicuculline improved memory (Chavez et al., 1995, Luft et al., 2004, Yousefi et al., 2012). Also, there are reports showing that bicuculline impaired memory (Chavez et al., 1995, Moron et al., 2002, Gibbs and Johnston, 2005). The result of current investigation indicated that post-training intra-CA1 injection of muscimol decreased memory consolidation but did not change locomotor activity. GABA is one of the main inhibitory neurotransmitters in the central nervous system (CNS). It opens chloride channels in a cell via mediating its $\mathrm{GABA}_{\mathrm{A}}$ receptors and therefore hyperpolarizes the cell (Barnard et al., 1998, Costa, 1998). Lehoullier and Ticku (1987) reported that $\mathrm{GABA}_{\mathrm{A}}$ agonists excite ${ }^{36} \mathrm{Cl}$-influx in the spinal cord neurons in a concentration-dependent manner (Lehoullier and Ticku, 1987). It seems that muscimol via activating $\mathrm{GABA}_{\mathrm{A}}$ 
receptors opens chloride channels and hyperpolarizes the CA1 neurons, hence impaired IA memory consolidation. Behavioral studies have revealed that posttraining administration of muscimol into the hippocampus, amygdala, septum, or VTA impaired IA memory (Brioni and McGaugh, 1988, Brioni et al., 1989, Castellano et al., 1989, Brioni et al., 1990, Castellano and McGaugh, 1990, Tomaz et al., 1993, Farkas and Crowe, 2000). According to previous researches (Castellano and McGaugh, 1990, Nakagawa and Iwasaki, 1995, Zarrindast et al., 2004, Yousefi et al., 2012, Yousefi et al., 2013), the present data also indicate that muscimol impaired memory. Generally, $\mathrm{GABA}_{\mathrm{A}}$ agonists, such as muscimol, impair retention, while antagonists increase it. These results provide strong evidence for the view that the $\mathrm{GABA}_{\mathrm{A}}$ receptors modulate post-training processes underlying memory consolidation (Castellano and McGaugh, 1990, AmmassariTeule et al., 1991, Luft et al., 2004).

Moreover, the results of this research showed that post-training i.p. administration of harmane impaired memory consolidation but had no significant effect on locomotor activity. The pharmacological investigations demonstrated that $\beta$-carbolines alkaloids are found in the brain and to a certain extent affect the central and peripheral nervous systems (Glushkov, 1982, Farzin and Mansouri, 2006, Rook et al., 2010). Furthermore, autoradiographical researches and radioligand binding revealed that $[3 \mathrm{H}]$-harmane was found in the CNS for example 
the hypothalamus, hippocampus, cerebral cortex, striatum, cerebellum and spinal cord (Anderson et al., 2006). Functional characterization of harmane and related compounds has shown a complex pharmacology following exogenous injection (Rommelspacher et al., 1994). It has been suggested that harmane acts as an endogenous ligands at imidazoline and benzodiazepine binding site of the $\mathrm{GABA}_{\mathrm{A}}$ receptors (Rommelspacher et al., 1980, 1981, Husbands et al., 2001, Musgrave et al., 2003), with the effect of weakening neuronal excitation through inhibition of voltage-gated calcium channel currents (Martin et al., 1997). Up to now, the effective concentration of harmane around the neurons is not well-known and effective levels range from $10^{-10}$ to $10^{-4} \mathrm{M}[1-3]$. It has been reported that harmane has a number of effects on the CNS function indicating to its importance as a neuromodulator (Celikyurt et al., 2013). Previous behavioral evidences have revealed a number of different effects for harmane, e.g. convulsive or anticonvulsive, antioxidative, tremorogenesis action (el Bahri and Chemli, 1991, Farzin and Mansouri, 2006), anxiolytic, antidepressant effect (Aricioglu and Altunbas, 2003), anti-allodynic effect in both mononeuropathic and acute pain (Aricioglu et al., 2003), and reinforcement of alcohol consumption in rats (Myers and Melchior, 1977, Rommelspacher et al., 1987). In addition, there are diverse results regarding the effects of $\beta$-carboline alkaloids on learning and memory processes. These alkaloids may decrease (Du and Harvey, 1997), or increase 
memory process (Moura et al., 2006). Similar to our study, evidence from some studies exhibited that i.p. injection of harmane impaired learning and memory formation including both acquisition (Celikyurt et al., 2013, Nasehi et al., 2013), and consolidation (Nasehi et al., 2010). However, there is a report showing that harmane did not influence formation of short and long term memories (Moura et al., 2006). On the other hand, it may induce some effects on non-spatial and nonaversive memory tasks and may also enhance long term memory (Moura et al., 2006). The controversial data may be due to differences in methods, route of injection and/or the doses of drugs used. Harmane has a fully unsaturated pyridine ring, but no group substitution in $\mathrm{C}$, which explain its lack of activity in memory enhancement (Moura et al., 2006). As regards harmane inhibited voltage-gated calcium channel currents and so reduced neuronal excitation (Martin et al., 1997, Splettstoesser et al., 2005), it could decrease memory consolidation.

In the next section of this paper, we investigate the involvement of $\mathrm{GABA}_{\mathrm{A}}$ receptors on amnesia induced by harmane. Our results displayed that in mice trained under post-training i.p. administration of harmane, post-training intra-CA1 injection of a sub-threshold dose of bicuculline and muscimol significantly modifies memory consolidation induced by higher doses of harmane. These interventions did not alter locomotor activity. The $\beta$-carboline alkaloids display modest affinity to serotonin, dopamine and benzodiazepine binding site of the 
$\mathrm{GABA}_{\mathrm{A}}$ receptors. This affinity is highly dependent upon substitutions and ring saturation. The fully aromatic $\beta$-carbolines indicate more affinity to these receptors and the substitution in $\mathrm{C} 7$ also appears to be essential in modifying its affinity for these receptors (Glennon et al., 2000). Some studies reported that harmane enhances the electrically stimulated release of the transmitter by the GABAergic axons (Dolzhenko and Komissarov, 1984). The GABA-potentiating action of harmane is probable due to the blockade of the voltage-dependent $\mathrm{K}^{+}$channels and enhancement of the intracellular concentration of $\mathrm{Ca}^{2+}$ (Abramets and Komissarov, 1984). The enhancement of memory consolidation induced by post-training administration of harmane and bicuculline may be related to elevation of intracellular concentration of calcium. On the other hand, it is a possible that harmane by decreasing neuronal excitation and muscimol via hyperpolarization of the CA1 neurons intensely impaired memory consolidation.

Thus, present results indicated that there was an interaction between the $\mathrm{GABA}_{\mathrm{A}}$ receptors and $\beta$-carbolines alkaloids on IA memory consolidation in the CA1. More interestingly, we found the additive effect of harmane and muscimol upon induction of memory deficits, by isobolographic analysis. As mentioned above, harmane stimulated the GABAergic axons (Dolzhenko and Komissarov, 1984). Chloride ionophore complex of the $\mathrm{GABA}_{\mathrm{A}}$ receptor comprises of some receptor protein subunits responsible for its diverse functional properties (Blair et 
al., 1988). $\beta$-Carboline agonists caused a left shift of the GABA concentrationchloride uptake curve or a reduction in the maximal enhance in GABA-stimulated ${ }^{36} \mathrm{Cl}^{-}$uptake depending on their concentration (Malatynska et al., 1992). The benzodiazepine site on the GABA receptor is the main site of action for a number of structurally different compounds such as the $\beta$-carbolines which bind with high affinity (Skerritt and Macdonald, 1984, Gessi et al., 1999). Biochemical, electrophysiological and behavioral studies demonstrated that $\beta$-carboline alkaloids interact with the benzodiazepines receptors to either facilitate or inhibit GABAmediated $\mathrm{Cl}^{-}$channel function (Lehoullier and Ticku, 1987, Malatynska et al., 1988). This modulation may, at least in part, be related to changes in the GABA receptor affinity (Lehoullier and Ticku, 1987). Harmane has a GABA-potentiating effect due to its main action on chloride ionophores coupled with the GABA receptor (Komissarov and Abramets, 1982). A probable mechanism for memory impairment induced by administration of harmane and muscimol might be due to the binding of harmane to the GABA receptor complex. The enhancement of GABA activated chloride conductance through $\beta$-carboline is produced via an allosteric mechanism that can be confirmed by pharmacological methods (Obata et al., 1988). Such allosteric interactions are noncompetitive, including an alteration in the conformation of one site due to the presence of a ligand at a second site (Malatynska et al., 1992). Our study indicated that harmane and the GABAergic 
neurons interact with each other. More experiments are required to determine exact function of harmane and the GABAergic neurons in modulation of memory.

\section{Conclusion}

The current investigation showed that post-training intra-CA1 injections of bicuculline did not change, whereas muscimol decreased memory consolidation. Moreover, post-training i.p. administration of harmane impaired memory consolidation. Furthermore, in our experiments post-training intra-CA1 administration of bicuculline restored, while muscimol potentiated impairment of memory consolidation produced by harmane. In addition, the isobologram analysis indicated that there is an additive effect between harmane and muscimol on impairment of memory consolidation. Consequently, harmane and GABA mechanisms interact with each other in the CA1 region. Nonetheless, further studies are required to clarify the interaction between harmane and GABA systems in the modulation of memory in the CA1 area.

\section{Acknowledgments}

The authors thank the Iran National Science Foundation (INSF) for providing the financial support for the project. 


\section{References}

Abramets, II, Komissarov IV (1984) [Ion-dependency of the GABA-potentiating effects of benzodiazepine tranquilizers and harmane]. Biulleten' eksperimental'noi biologii i meditsiny 97:679-681.

Ammassari-Teule M, Pavone F, Castellano C, McGaugh JL (1991) Amygdala and dorsal hippocampus lesions block the effects of GABAergic drugs on memory storage. Brain research 551:104-109.

Anderson NJ, Tyacke RJ, Husbands SM, Nutt DJ, Hudson AL, Robinson ES (2006) In vitro and ex vivo distribution of $[3 \mathrm{H}]$ harmane, an endogenous beta-carboline, in rat brain. Neuropharmacology 50:269-276.

Aricioglu F, Altunbas H (2003) Harmane induces anxiolysis and antidepressant-like effects in rats. Annals of the New York Academy of Sciences 1009:196-201.

Aricioglu F, Korcegez E, Ozyalcin S (2003) Effect of harmane on mononeuropathic pain in rats. Annals of the New York Academy of Sciences 1009:180-184.

Azizbeigi R, Zarrindast MR, Ahmadi S (2013) Interaction between gamma-aminobutyric acid type A (GABAA) receptor agents and scopolamine in the nucleus accumbens on impairment of inhibitory avoidance memory performance in rat. Behavioural brain research 241:191-197.

Barnard EA, Skolnick P, Olsen RW, Mohler H, Sieghart W, Biggio G, Braestrup C, Bateson AN, Langer SZ (1998) International Union of Pharmacology. XV. Subtypes of gamma-aminobutyric acidA receptors: classification on the basis of subunit structure and receptor function. Pharmacological reviews 50:291-313.

Blair LA, Levitan ES, Marshall J, Dionne VE, Barnard EA (1988) Single subunits of the GABAA receptor form ion channels with properties of the native receptor. Science 242:577-579.

Bonnet U, Scherbaum N, Wiemann M (2008) The endogenous alkaloid harmane: acidifying and activityreducing effects on hippocampal neurons in vitro. Progress in neuro-psychopharmacology \& biological psychiatry 32:362-367.

Bormann J (2000) The 'ABC' of GABA receptors. Trends in pharmacological sciences 21:16-19.

Bowery NG (1993) GABAB receptor pharmacology. Annual review of pharmacology and toxicology 33:109-147.

Brioni JD, Decker MW, Gamboa LP, Izquierdo I, McGaugh JL (1990) Muscimol injections in the medial septum impair spatial learning. Brain research 522:227-234.

Brioni JD, McGaugh JL (1988) Post-training administration of GABAergic antagonists enhances retention of aversively motivated tasks. Psychopharmacology 96:505-510.

Brioni JD, Nagahara AH, McGaugh JL (1989) Involvement of the amygdala GABAergic system in the modulation of memory storage. Brain research 487:105-112.

Castellano C, Brioni JD, Nagahara AH, McGaugh JL (1989) Post-training systemic and intra-amygdala administration of the GABA-B agonist baclofen impairs retention. Behavioral and neural biology 52:170-179.

Castellano C, McGaugh JL (1990) Effects of post-training bicuculline and muscimol on retention: lack of state dependency. Behavioral and neural biology 54:156-164.

Celikyurt IK, Utkan T, Gocmez SS, Hudson A, Aricioglu F (2013) Effect of harmane, an endogenous betacarboline, on learning and memory in rats. Pharmacology, biochemistry, and behavior 103:666671.

Chapouthier G, Venault P (2002) GABA-A receptor complex and memory processes. Current topics in medicinal chemistry 2:841-851.

Chavez ME, Salado-Castillo R, Sanchez-Alavez M, Quirarte GL, Prado-Alcala RA (1995) Post-training injection of GABAergic antagonists into the striatum produces retrograde amnesia. Neurobiology of learning and memory 63:296-300. 
Costa E (1998) From GABAA receptor diversity emerges a unified vision of GABAergic inhibition. Annual review of pharmacology and toxicology 38:321-350.

Dolzhenko AT, Komissarov IV (1984) [GABA-ergic effects of harman independent of its influence on benzodiazepine receptors]. Biulleten' eksperimental'noi biologii i meditsiny 98:446-448.

Drake CT, Milner TA (1999) Mu opioid receptors are in somatodendritic and axonal compartments of GABAergic neurons in rat hippocampal formation. Brain research 849:203-215.

Du W, Harvey JA (1997) Harmaline-induced tremor and impairment of learning are both blocked by dizocilpine in the rabbit. Brain research 745:183-188.

el Bahri L, Chemli R (1991) Peganum harmala L: a poisonous plant of North Africa. Veterinary and human toxicology 33:276-277.

Ergene E, Schoener EP (1993) Effects of harmane (1-methyl-beta-carboline) on neurons in the nucleus accumbens of the rat. Pharmacology, biochemistry, and behavior 44:951-957.

Farahmandfar M, Zarrindast MR, Kadivar M, Karimian SM, Naghdi N (2011) The effect of morphine sensitization on extracellular concentrations of GABA in dorsal hippocampus of male rats. European journal of pharmacology 669:66-70.

Farkas L, Crowe SF (2000) The role of the benzodiazepine-GABA system in the memory processes of the day-old chick. Pharmacology, biochemistry, and behavior 65:223-231.

Farr SA, Flood JF, Morley JE (2000) The effect of cholinergic, GABAergic, serotonergic, and glutamatergic receptor modulation on posttrial memory processing in the hippocampus. Neurobiology of learning and memory 73:150-167.

Farzin D, Mansouri N (2006) Antidepressant-like effect of harmane and other beta-carbolines in the mouse forced swim test. European neuropsychopharmacology : the journal of the European College of Neuropsychopharmacology 16:324-328.

Gessi S, Dalpiaz A, Varani K, Borea PA (1999) Temperature dependence and GABA modulation of betacarboline binding to rat cerebellum benzodiazepine receptors. Life sciences 64:PL185-192.

Gibbs ME, Johnston GA (2005) Opposing roles for GABAA and GABAC receptors in short-term memory formation in young chicks. Neuroscience 131:567-576.

Glennon RA, Dukat M, Grella B, Hong S, Costantino L, Teitler M, Smith C, Egan C, Davis K, Mattson MV (2000) Binding of beta-carbolines and related agents at serotonin (5-HT(2) and 5-HT(1A)), dopamine $(D(2))$ and benzodiazepine receptors. Drug and alcohol dependence 60:121-132.

Glushkov RG, Filenko, N.I., Mashkovskii, M.D., Andreeva, N.I., Sozinov, V.N., Sozinov, V.N., (1982) Synthesis and pharmacological activity of pyrazino-b-carboline derivetives. Plenum publishing corporation 16:1054-1058.

Herraiz T, Chaparro C (2006) Human monoamine oxidase enzyme inhibition by coffee and betacarbolines norharman and harman isolated from coffee. Life sciences 78:795-802.

Heysieattalab S, Naghdi N, Zarrindast MR, Haghparast A, Mehr SE, Khoshbouei H (2015) The effects of GABA and NMDA receptors in the shell-accumbens on spatial memory of METH-treated rats. Pharmacology, biochemistry, and behavior 142:23-35.

Husbands SM, Glennon RA, Gorgerat S, Gough R, Tyacke R, Crosby J, Nutt DJ, Lewis JW, Hudson AL (2001) beta-carboline binding to imidazoline receptors. Drug and alcohol dependence 64:203208.

Jafari-Sabet M, Jannat-Dastjerdi I (2009) Muscimol state-dependent memory: involvement of dorsal hippocampal mu-opioid receptors. Behavioural brain research 202:5-10.

Kangarlu-Haghighi K, Oryan S, Nasehi M, Zarrindast MR (2015) The effect of BLA GABA(A) receptors in anxiolytic-like effect and aversive memory deficit induced by ACPA. EXCLI journal 14:613-626.

Khakpai F, Nasehi M, Haeri-Rohani A, Eidi A, Zarrindast MR (2013a) Septo-hippocampo-septal loop and memory formation. Basic and clinical neuroscience 4:5-23. 
Khakpai F, Zarrindast M, Nasehi M, Haeri-Rohani A, Eidi A (2013b) The role of glutamatergic pathway between septum and hippocampus in the memory formation. EXCLI Journal 12:41-51.

Komissarov IV, Abramets, II (1982) [Characteristics of GABA-potentiating effect of harman]. Biulleten' eksperimental'noi biologii i meditsiny 94:61-63.

Lehoullier PF, Ticku MK (1987) Benzodiazepine and beta-carboline modulation of GABA-stimulated 36Clinflux in cultured spinal cord neurons. European journal of pharmacology 135:235-238.

Luft T, Pereira GS, Cammarota M, Izquierdo I (2004) Different time course for the memory facilitating effect of bicuculline in hippocampus, entorhinal cortex, and posterior parietal cortex of rats. Neurobiology of learning and memory 82:52-56.

Malatynska E, Giroux ML, Dilsaver SC, Schwarzkopf SB (1992) Bidirectional effect of beta-carboline agonists at the benzodiazepine-GABAA receptor chloride ionophore complex on GABAstimulated $36 \mathrm{Cl}$ - uptake. Brain research bulletin 28:605-611.

Malatynska E, Serra M, Ikeda M, Biggio G, Yamamura HI (1988) Modulation of GABA-stimulated chloride influx by beta-carbolines in rat brain membrane vesicles. Brain research 443:395-397.

Martin L, Martin MA, del Castillo B (1997) Changes in acid-base equilibria of harmine and harmane inclusion complexes with cyclodextrins. Biomedical chromatography : BMC 11:87-88.

McDonald BJ, Moss SJ (1994) Differential phosphorylation of intracellular domains of gammaaminobutyric acid type A receptor subunits by calcium/calmodulin type 2-dependent protein kinase and cGMP-dependent protein kinase. The Journal of biological chemistry 269:1811118117.

McKenna DJ (1996) Plant hallucinogens: springboards for psychotherapeutic drug discovery. Behavioural brain research 73:109-116.

Moron I, Ramirez-Lugo L, Ballesteros MA, Gutierrez R, Miranda MI, Gallo M, Bermudez-Rattoni F (2002) Differential effects of bicuculline and muscimol microinjections into the nucleus basalis magnocellularis in taste and place aversive memory formation. Behavioural brain research 134:425-431.

Moura DJ, Rorig C, Vieira DL, Henriques JA, Roesler R, Saffi J, Boeira JM (2006) Effects of beta-carboline alkaloids on the object recognition task in mice. Life sciences 79:2099-2104.

Mousah H, Jacqmin P, Lesne M (1986) Interaction of carbolines and some GABA receptor ligands with the GABA and the benzodiazepine receptors. Journal de pharmacologie 17:686-691.

Muller WE, Fehske KJ, Borbe HO, Wollert U, Nanz C, Rommelspacher H (1981) On the neuropharmacology of harmane and other beta-carbolines. Pharmacology, biochemistry, and behavior 14:693-699.

Musgrave IF, Van Der Zypp A, Grigg M, Barrow CJ (2003) Endogenous imidazoline receptor ligands relax rat aorta by an endothelium-dependent mechanism. Annals of the New York Academy of Sciences 1009:222-227.

Myers RD, Melchior CL (1977) Differential actions on voluntary alcohol intake of tetrahydroisoquinolines or a beta-carboline infused chronically in the ventricle of the rat. Pharmacology, biochemistry, and behavior 7:381-392.

Nakagawa Y, Iwasaki T (1995) Involvement of benzodiazepine/GABA-A receptor complex in ethanolinduced state-dependent learning in rats. Brain research 686:70-76.

Nasehi M, Mashaghi E, Khakpai F, Zarrindast MR (2013) Suggesting a possible role of CA1 histaminergic system in harmane-induced amnesia. Neuroscience letters 556:5-9.

Nasehi M, Piri M, Nouri M, Farzin D, Nayer-Nouri T, Zarrindast MR (2010) Involvement of dopamine D1/D2 receptors on harmane-induced amnesia in the step-down passive avoidance test. European journal of pharmacology 634:77-83. 
Naseri MH, Hesami-Tackallou S, Torabi-Nami M, Zarrindast MR, Nasehi M (2014) Involvement of the CA1 GABAA receptors in MK-801-induced anxiolytic-like effects: an isobologram analysis. Behavioural pharmacology 25:197-205.

Obata T, Morelli M, Concas A, Serra M, Yamamura HI (1988) Modulation of GABA-stimulated chloride influx into membrane vesicles from rat cerebral cortex by benzodiazepines and nonbenzodiazepines. Advances in biochemical psychopharmacology 45:175-187.

Parsaei L, Rangchiyan M, Ahmadi S, Zarrindast MR (2011) GABA A Receptors in the Dorsal Hippocampus are Involved in Sate-dependent Learning Induced by Lithium in Mice. Iranian journal of pharmaceutical research : IJPR 10:127-134.

Paulsen O, Moser El (1998) A model of hippocampal memory encoding and retrieval: GABAergic control of synaptic plasticity. Trends in neurosciences 21:273-278.

Paxinos G, Franklin KBJ (2001) The Mouse Brain in Stereotaxic Coordinates. 2nd Ed Academic Press.

Ramirez DR, Buzzetti RA, Savage LM (2005) The role of the GABA(A) agonist muscimol on memory performance: reward contingencies determine the nature of the deficit. Neurobiol Learn Mem 84:184-191.

Rommelspacher H, Buchau C, Weiss J (1987) Harman induces preference for ethanol in rats: is the effect specific for ethanol? Pharmacology, biochemistry, and behavior 26:749-755.

Rommelspacher H, May T, Salewski B (1994) Harman (1-methyl-beta-carboline) is a natural inhibitor of monoamine oxidase type $A$ in rats. European journal of pharmacology 252:51-59.

Rommelspacher H, Nanz C, Borbe HO, Fehske KJ, Muller WE, Wollert U (1980) 1-Methyl-beta-carboline (harmane), a potent endogenous inhibitor of benzodiazepine receptor binding. NaunynSchmiedeberg's archives of pharmacology 314:97-100.

Rommelspacher H, Nanz C, Borbe HO, Fehske KJ, Muller WE, Wollert U (1981) Benzodiazepine antagonism by harmane and other beta-carbolines in vitro and in vivo. European journal of pharmacology 70:409-416.

Rook Y, Schmidtke KU, Gaube F, Schepmann D, Wunsch B, Heilmann J, Lehmann J, Winckler T (2010) Bivalent beta-carbolines as potential multitarget anti-Alzheimer agents. Journal of medicinal chemistry 53:3611-3617.

Semyanov A, Kullmann DM (2002) Relative picrotoxin insensitivity distinguishes ionotropic GABA receptor-mediated IPSCs in hippocampal interneurons. Neuropharmacology 43:726-736.

Skerritt JH, Macdonald RL (1984) Benzodiazepine receptor ligand actions on GABA responses. Betacarbolines, purines. European journal of pharmacology 101:135-141.

Splettstoesser F, Bonnet U, Wiemann M, Bingmann D, Busselberg D (2005) Modulation of voltage-gated channel currents by harmaline and harmane. British journal of pharmacology 144:52-58.

Thompson SM (1994) Modulation of inhibitory synaptic transmission in the hippocampus. Progress in neurobiology 42:575-609.

Tomaz C, Dickinson-Anson H, McGaugh JL, Souza-Silva MA, Viana MB, Graeff FG (1993) Localization in the amygdala of the amnestic action of diazepam on emotional memory. Behavioural brain research 58:99-105.

Yousefi B, Farjad M, Nasehi M, Zarrindast MR (2013) Involvement of the CA1 GABAA receptors in ACPAinduced impairment of spatial and non-spatial novelty detection in mice. Neurobiology of learning and memory 100:32-40.

Yousefi B, Nasehi M, Khakpai F, Zarrindast MR (2012) Possible interaction of cholinergic and GABAergic systems between MS and CA1 upon memory acquisition in rats. Behavioural brain research 235:231-243.

Zarrindast MR, Noorbakhshnia M, Motamedi F, Haeri-Rohani A, Rezayof A (2006) Effect of the GABAergic system on memory formation and state-dependent learning induced by morphine in rats. Pharmacology 76:93-100. 
Zarrindast MR, Shamsi T, Azarmina P, Rostami P, Shafaghi B (2004) GABAergic system and imipramineinduced impairment of memory retention in rats. European neuropsychopharmacology : the journal of the European College of Neuropsychopharmacology 14:59-64. 


\section{Legends}

Table 1 explains experimental design.

Fig. 1. The effects of saline, bicuculline and muscimol on step-down latency and locomotor activity. The animals received saline ( $1 \mu \mathrm{l} / \mathrm{mouse})$, bicuculline (0.001, 0.01, and $0.1 \mu \mathrm{g} /$ mouse, left panel) and muscimol (0.001, 0.01 , and 0.1 $\mu \mathrm{g} /$ mouse, right panel) just after training. The memory was recorded $24 \mathrm{~h}$ after infusion of drugs. Moreover, locomotor activity was examined after memory testing. The step-down latency bars are expressed as median and quartile while locomotion bars are in mean \pm S.E.M. $(\mathrm{n}=10$, all groups; $* * * \mathrm{P}<0.001$ when compared to saline/saline group).

Fig. 2. Left panel indicates the effects of harmane $(1,3$ and $5 \mathrm{mg} / \mathrm{kg})$ on memory consolidation and locomotor activity. Middle and right panels display the effects of bicuculline (0.001 $\mu \mathrm{g} /$ mouse) and muscimol (0.001 $\mu \mathrm{g} /$ mouse), respectively with harmane $(1,3$ and $5 \mathrm{mg} / \mathrm{kg})$ on memory consolidation and locomotor activity. The memory was measured $24 \mathrm{~h}$ after injection of drugs. Furthermore, locomotor activity was examined after memory testing. The stepdown latency bars are expressed as median and quartile but locomotion bars are in mean \pm S.E.M. $(\mathrm{n}=10$, all groups; $* \mathrm{P}<0.05$, and $* * * \mathrm{P}<0.001$ when compared to 
saline/saline group. $+\mathrm{p}<0.05$ and $++\mathrm{p}<0.01$ when compared with harmane/saline group).

Fig. 3. The isobologram analysis of the effects of drugs administration reveals the additive effect of intra-CA1 injection of harmane and muscimol to induce memory consolidation deficit. The foci A and B mean indicate the ED50 of harmane and muscimol, respectively. In Brief, the ED50 of each drug $(2.66 \mathrm{mg} / \mathrm{kg}$ for harmane and $0.052 \mathrm{mg} / \mathrm{kg}$ for muscimol was calculated by linear regression analysis. The oblique line between A and B is the theoretic additive effect line of harmane and muscimol administrations. The focus $\mathrm{C}$, in the middle of line, is the theoretical ED50 of the drug combination, which is calculated from the individual drug ED50. The focus D, far below the line, is the experimental ED50 of drugs combination, which is actually observed after drugs injection. Statistical analysis revealed that there is no significant difference between experimental ED50 and theoretical ED50 points, suggesting an additive effect of the drugs administration (for more details see the statistical analysis section). ED50, effective dose 50.

Fig. 4. Approximate location of the injection cannulae tips in the CA1 regions for all mice included in the data analyses was taken from the atlas of Paxinos and Franklin (Paxinos and Franklin, 2001). 


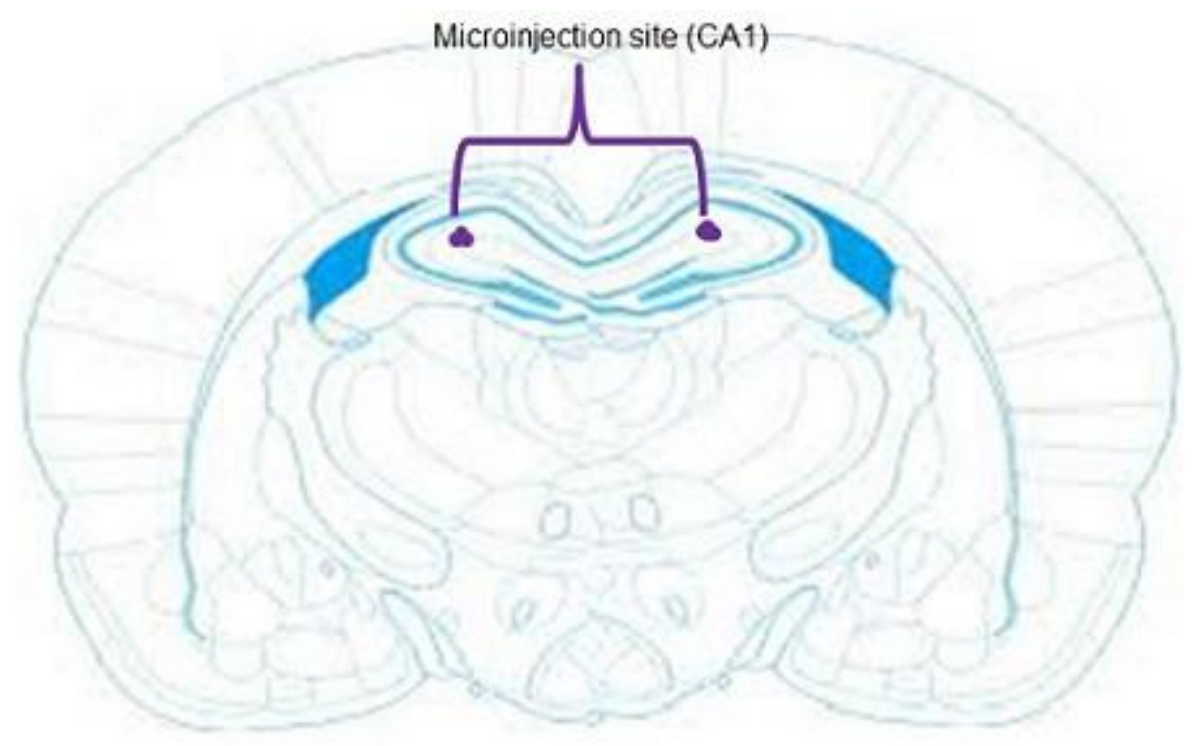

Fig. 1 


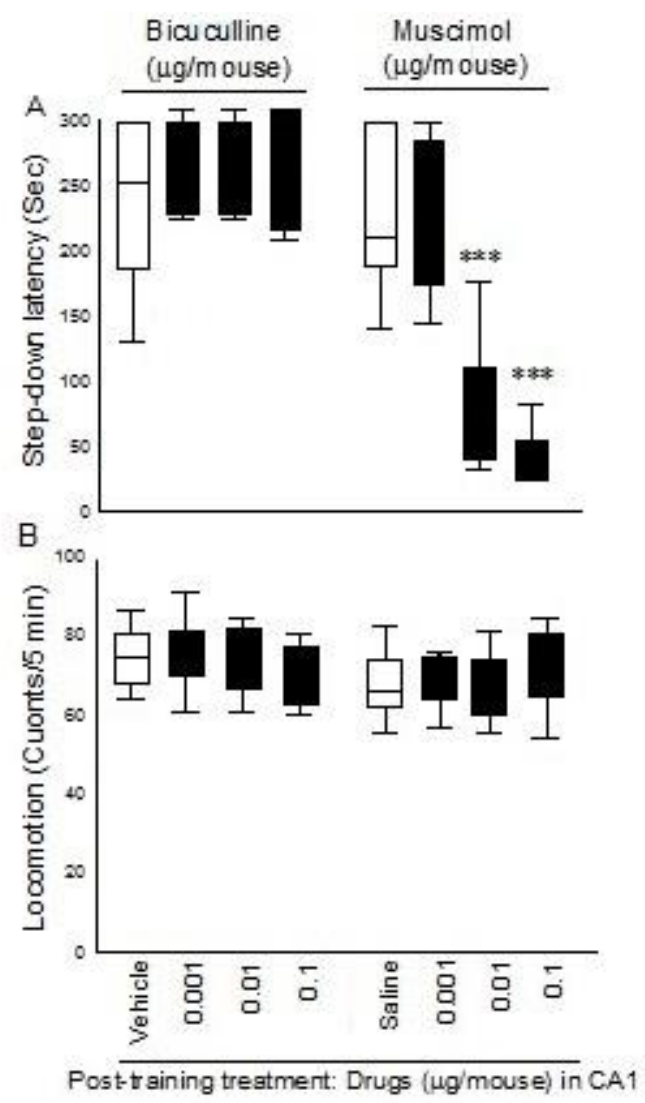

Fig. 2 

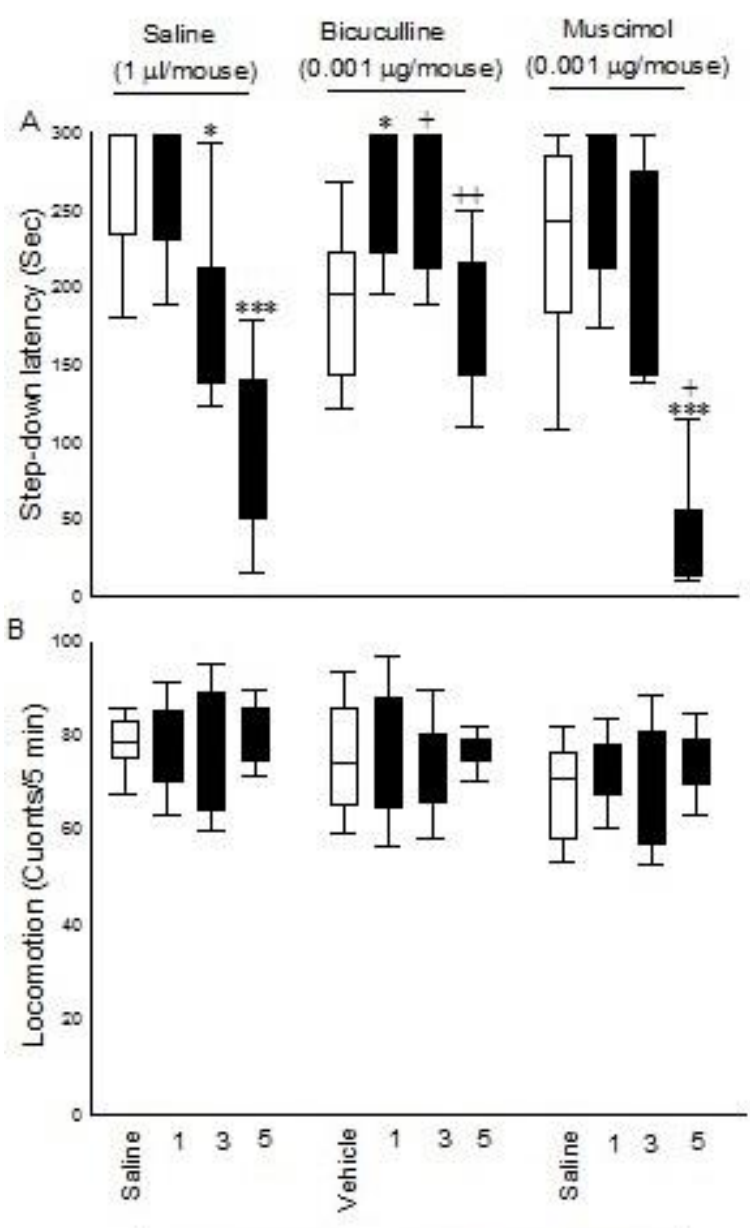

Post-training treatment Harmane (mg/kg)

Fig. 3 


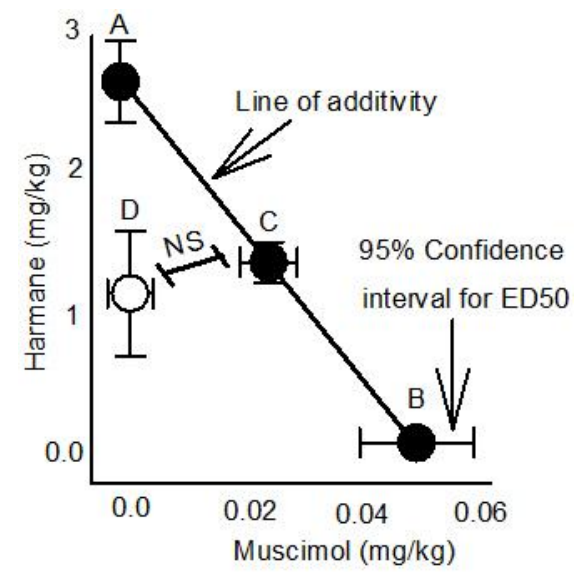

Fig. 4 


\section{Table 1}

The table describes experiments, groups of animals and doses of drugs.

\begin{tabular}{|c|c|c|c|c|c|}
\hline Experiment & Figure & Post-training treatment (i.p.) & Post-training treatment (intra-CA1) & $\begin{array}{c}\text { Step-down latency } \\
\text { (Panel A) }\end{array}$ & $\begin{array}{c}\text { Locomotor activity } \\
\text { (Panel B) }\end{array}$ \\
\hline \multirow[t]{2}{*}{1} & Left & - & bicuculline $(0.001,0.01$, and $0.1 \mu \mathrm{g} / \mathrm{mouse})$ & No effect & No effect \\
\hline & Right & - & muscimol $(0.001,0.01$, and $0.1 \mu \mathrm{g} /$ mouse $)$ & Decrease & No effect \\
\hline \multirow[t]{3}{*}{2} & Left & harmane $(1,3$ and $5 \mathrm{mg} / \mathrm{kg})$ & Saline $(1 \mu 1 /$ mouse $)$ & Decrease & No effect \\
\hline & Middle & harmane $(1,3$ and $5 \mathrm{mg} / \mathrm{kg})$ & bicuculline $(0.001 \mu \mathrm{g} / \mathrm{mouse})$ & Increase & No effect \\
\hline & Right & harmane $(1,3$ and $5 \mathrm{mg} / \mathrm{kg})$ & muscimol $(0.001 \mu \mathrm{g} /$ mouse $)$ & Decrease & No effect \\
\hline
\end{tabular}

